\title{
Hubungan antara Minat dan Kebahagiaan menjadi Perajin Ukir Kayu Jepara
}

\author{
Achmad Tasylichul Adib \\ Badan Pusat Statistik (BPS) Sekadau, Kalimantan Barat \\ Korespondensi: Achmad Tasylichul Adib (e-mail: dibtasylichul@bps.go.id)
}

\begin{abstract}
Abstrak
Sejak tahun 2004-2015, jumlah perajin ukir kayu Jepara mengalami penurunan. Fenomena ini terjadi akibat kurangnya minat masyarakat untuk menjadi perajin ukir kayu. Ironisnya, mereka yang masih menjadi perajin saat ini, justru menjual harga ukiran dengan harga berapa pun untuk mencukupi kebutuhan. Kajian mengenai kebahagiaan kerja perajin ukir kayu perlu dilakukan. Tujuannya adalah untuk mengetahui pengaruh minat perajin terhadap kebahagiaannya berdasarkan karakteristik sosial ekonomi. Populasi dalam penelitian ini adalah seluruh industri mikro kecil ukir kayu. Penarikan sampel dilakukan dengan metode stratified systematic sampling menggunakan kerangka sampel dari data listing SE 2016. Dari 837 usaha, diperoleh sampel sebanyak 100 usaha yang distratakan menjadi sentra, yaitu 53 usaha dan strata non sentra, yaitu 47 usaha. Metode analisis yang digunakan adalah analisis deskriptif (tabel dan grafik) dan analisis inferensia (uji kebebasan dan regresi logistik biner). Hasil survei menunjukkan bahwa minat memiliki kecenderungan untuk memengaruhi kebahagiaan perajin. Namun, kecenderungan tertinggi yang memengaruhi perajin untuk bahagia adalah besarnya pendapatan.
\end{abstract}

Kata kunci: kebahagiaan; minat; perajin ukir kayu Jepara; regresi logistik biner

\section{The Assosiation of Interests in Prefecting Profession with Happiness as a Jepara Woodcarvers}

\begin{abstract}
Since 2004-2015, there has been a decline in the number of Jeparawoodcarvers. This phenomenon is allegedly caused by the lack of interest as woodcarvers. Ironically, those who are survive today, actually sell the carving at any price. The study about woodcarvers happiness was conducted to determine the effect of interest on happiness based on socioeconomic characteristics. The population of this study was all of the small-micro wood carving industries. The sampling was carried out using the stratified systematic sampling method with sample framework SE 2016 listing data. A total of 837 industry were allocated to 100 industry and were stratified into centers of 53 industries and non-centers of 47 industries. The analytical method used descriptive analysis and inferencing analysis. This study revealed that interest has a tendency to influence woodcarvers happiness, but the amount of income becomes its highest factor.
\end{abstract}

Keywords: binary logistic regression; happiness; interest; Jepara Woodcarvers 


\section{Pendahuluan}

Jepara dikenal sebagai pusat industri mebel ukir di Indonesia. Produk-produk industri mebel ukir Jepara telah berhasil memasuki pasar internasional dan global. Kehadiran produk seni ukir Jepara mendapat tanggapan positif dari konsumen mancanegara, terutama di Asia, Eropa Barat, dan Amerika, sehingga Jepara dijuluki sebagai Kota Ukir atau The Carving Centre of Indonesia (Gustami, 2000: 4). Hal ini juga dibuktikan dengan data Badan Pusat Statistik (BPS) Kabupaten Jepara pada 2004, yaitu terdapat 85.270 dari 139.781 (61\%) jiwa usia produktif yang bekerja sebagai perajin ukir kayu. Keadaan tersebut membawa Kabupaten Jepara dalam masa kejayaan. Menurut Dinas Perindustrian dan Perdagangan (Disperindag) Kabupaten Jepara, industri mebel ukir Jepara mampu menghasilkan rata-rata nilai produksi per tahun yang mencapai 1,24 triliun dalam dekade terakhir.

Namun pada 2015, terjadi penurunan jumlah perajin ukir kayu menjadi 75.603 dari 143.538 (53\%) jiwa usia produktif yang bekerja sebagai perajin ukir kayu. Penurunan tersebut cukup besar, mengingat profesi perajin ukir kayu merupakan profesi yang paling diminati dalam dekade terakhir. Dampak dari penurunan jumlah perajin ukir adalah menurunnya nilai ekspor mebel ukir Jepara dari yang semula senilai US \$135 juta pada 2013 menjadi US \$102 juta pada 2014 (Disperindag, 2016).

Berkurangnya jumlah perajin ukir kayu Jepara ini berkaitan dengan kurangnya minat generasi penerus terhadap profesi sebagai perajin ukir kayu. Menurut Elizabeth (2008: 87 ), turunnya minat menjadi profesi perajin ukir kayu disebabkan semakin mahalnya harga produksi suatu barang dan proses pemasaran yang susah. Tazqiyah (2010: 92) juga mengemukakan, minat anak keluarga perajin ukir kayu umumnya memiliki cita-cita yang ingin diwujudkan sehingga tidak memilih berprofesi sebagai perajin ukir. Priyanto (2016) juga mengungkapkan bahwa kurangnya minat menjadi perajin ukir disebabkan upah yang rendah. Selain itu, adanya kompetitor ukiran dari Tiongkok dan daerah lain di Indonesia yang membuka sentra ukir dan pasar seni juga menjadi penyebab menurunnya jumlah perajin ukir di Jepara.

Meskipun minat sebagai profesi perajin ukir kayu berkurang, masih terdapat 5.993 industri ukir kayu yang tetap mempertahankan eksistensinya (Disperindag, 2016). Sejumlah industri ukir kayu yang masih bertahan memiliki rasa cinta terhadap profesi sebagai perajin ukir kayu. Selain itu, sikap melestarikan tradisi dan budaya yang diwariskan secara turun temurun juga membuat perajin ukir tetap menekuni profesinya (Priyanto, 2016).

Perajin ukir kayu dituntut untuk mencukupi kebutuhan sehari-hari, berupa kebutuhan untuk memproduksi ukiran dan kebutuhan dalam berumah tangga. Kebutuhan tersebut ditentukan oleh besarnya permintaan terhadap ukir kayu Jepara. Jumlah permintaan terhadap ukir kayu Jepara tentu saja memengaruhi kesejahteraan perajin ukir kayu (Priyanto, 2016). Apabila permintaan terhadap ukir kayu Jepara tinggi, maka perajin ukir kayu akan mendapat penghasilan yang tinggi, sehingga dapat mencukupi kebutuhan hidupnya dengan mudah. Namun apabila permintaan rendah, maka penghasilan yang didapatkan juga akan sedikit, sehingga mereka kesulitan dalam mencukupi kebutuhan sehari-hari.

Penelitian yang dilakukan oleh Center for International Forestry Research (CIFOR) pada 2012 menyebutkan bahwa realita yang terjadi saat ini adalah perajin ukir merasakan rendahnya permintaan terhadap ukir kayu Jepara, sehingga penghasilan yang diterima 
juga sedikit. Perajin ukir kayu Jepara yang masih bertahan dalam menekuni profesinya adalah perajin ukir yang dilandasi dengan rasa kecintaannya terhadap tradisi dan budaya turun-temurun, sehingga mereka bertahan dengan penghasilan berapa pun. Tidak jarang perajin ukir kayu Jepara juga menawarkan hasil ukiran yang harganya jauh lebih rendah dari harga produksinya.

Suatu pertanyaan muncul mengenai kebahagiaan perajin apabila kondisi yang dialami seperti yang telah disebutkan. Oleh sebab itu, penelitian ini bertujuan untuk mengetahui perbedaan minat dan kebahagiaan berdasarkan karakteristik sosial ekonomi perajin ukir kayu Jepara, serta menganalisis hubungan antara minat dan kebahagiaan perajin ukir kayu Jepara dalam menjalani profesinya sebagai perajin ukir kayu.

Penelitian terkait mengenai kebahagiaan kerja sudah pernah dilakukan oleh Diener (2003 : 34) yang menyatakan bahwa minat dan kepuasan kerja adalah faktor penting yang memengaruhi kebahagiaan. Selanjutnya, Alfarisi (2010 : 58-62) menyatakan, terdapat lima faktor yang memengaruhi kebahagiaan dalam bekerja, yaitu hubungan positif dengan orang lain $(47,2 \%)$, prestasi $(22,4 \%)$, lingkungan kerja fisik $(17,0 \%)$, kompensasi $(12,0 \%)$, dan kesehatan $(1,5 \%)$. Kemudian Soujanen (2012) mengemukakan bahwa kebahagiaan seseorang terhadap profesinya dipengaruhi oleh gaji, jam kerja, rekan kerja, lingkungan kerja, manajemen, dan sikap.

\section{Metodologi}

\section{Metode Pengumpulan Data}

Pengumpulan data penelitian ini dilakukan melalui dua cara, yaitu menggunakan data sekunder dan data primer.
1. Data Sekunder, data listing Sensus Ekonomi 2016 (SE 2016) Industri Mikro Kecil KBLI 3301 (Usaha Mebel, Furniture, dan Ukiran) BPS Kabupaten Jepara sebagai kerangka sampel.

2. Data Primer, pengumpulan data dilakukan dengan cara wawancara menggunakan kuesioner pada responden yang unit usahanya terpilih menjadi sampel. Teknik pengambilan sampel dalam penelitian ini menggunakan metode stratified systematic sampling. Awalnya, kerangka sampel distratakan ke dalam sentra dan non sentra. Kemudian dari masingmasing strata, sampel dipilih dengan menggunakan metode circular systematic sampling. Populasi dalam penelitian ini adalah seluruh usaha industri mikro kecil yang terdiri atas perajin ukir kayu Jepara, dimana industri mikro kecil yang tercatat pada data listing SE 2016 yaitu 837 usaha (kecuali usaha yang berlokasi di Kecamatan Kepulauan Karimun Jawa). Kemudian diperoleh sampel sebanyak 100 usaha yang dibagi ke dalam strata sentra, yaitu 53 usaha dan strata non sentra, yaitu 47 usaha.

\section{Metode Analisis}

Metode analisis dilakukan dengan dua cara sebagai berikut.

1. Analisis Deskriptif: bertujuan untuk menggambarkan profil perajin ukir kayu, latar belakang profesi perajin ukir kayu, serta minat dan kebahagiaan sebagai perajin ukir kayu berdasarkan karakteristik sosial ekonomi dengan menggunakan software Ms.Excel 2010 dan SPSS versi 22.0;

2. Analisis Inferensia: bertujuan untuk mengetahui pengaruh variabel penelitian terhadap minat maupun kebahagiaan 
Tabel 1. Variabel Penelitian

\begin{tabular}{|c|c|c|}
\hline Variabel & Nama Variabel & Kategori \\
\hline (1) & $(2)$ & (3) \\
\hline Y & Kebahagiaan perajin ukir kayu Jepara & $\begin{array}{l}0=\text { Cukup Bahagia* } \\
1=\text { Bahagia }\end{array}$ \\
\hline$X_{1}$ & Minat perajin ukir Kayu Jepara & $\begin{array}{l}0=\text { Cukup Berminat } \\
1=\text { Berminat }\end{array}$ \\
\hline$X_{2}$ & Wilayah/ tempat tinggal & $\begin{array}{l}0=\text { Desa } \\
1=\text { Kota }\end{array}$ \\
\hline$X_{3}$ & Tingkat Pendidikan & $\begin{aligned} 0= & \text { Tidak tamat } / \text { tamat } \\
& \text { pendidikan dasar* } \\
1= & \text { Tamat pendidikan } \\
& \text { selain dasar }\end{aligned}$ \\
\hline $\mathrm{X}_{4}$ & Pendapatan & $\begin{array}{l}0=<\operatorname{Rp} 450.000,00^{*} \\
1=\geq \operatorname{RP} 450.000,00\end{array}$ \\
\hline
\end{tabular}

sebagai perajin ukir kayu dengan melakukan uji test of independency dan regresi logistik biner. Regresi logistik biner meliputi uji simultan (Overall Test), uji parsial (Wald Test), uji ketepatan model (Hosmer and Lameshow Test), dan rasio kecenderungan (Odds Ratio) dengan menggunakan software SPSS versi 22.0.

\section{Pengategorian Variabel Penelitian}

Variabel dalam penelitian ini dikategorikan seperti terlihat pada Tabel 1.

\section{Hasil dan Pembahasan}

\section{Profil Perajin Ukir Kayu Jepara}

Sampel yang terpilih sebanyak 100 usaha mebel ukir kayu, dimana setiap usaha yang terpilih memiliki variasi jumlah pekerja antara satu hingga empat perajin (definisi jumlah pekerja yang tergolong industri mikro kecil). Kemudian didapatkan total jumlah perajin yang akan diwawancara sebanyak 287 perajin ukir kayu Jepara. Data mengenai karakteristik sosial ekonomi perajin digambarkan dalam profil perajin ukir kayu Jepara sebagaimana tercantum dalam Tabel 2. Berdasarkan Tabel 2, perajin ukir kayu Jepara mayoritas berjenis kelamin laki-laki. Sebagian besar perajin tinggal di desa. Tempat tinggal dalam penelitian ini bukan merupakan tempat bekerja. Berdasarkan tingkat pendidikannya, sebagian besar perajin ukir kayu di Jepara berpendidikan dasar dan menengah. Perajin berpendidikan dasar adalah mereka yang tidak lulus SD/MI, SD/MI, dan/atau SMP/MTs, sedangkan perajin berpendidikan menengah adalah mereka yang telah lulus SMASMK/MA. Kemudian perajin berpendidikan tinggi adalah mereka yang lulus perguruan tinggi, dalam hal ini adalah diploma dan sarjana. 
Tabel 2. Jumlah, Persentase, dan Rata-Rata Variabel Karakteristik Sosial Ekonomi Perajin Ukir Kayu Jepara

\begin{tabular}{|c|c|c|c|c|}
\hline \multicolumn{2}{|c|}{ Krakteristik Sosial Ekonomi Perajin Ukir Kayu } & \multirow{2}{*}{$\begin{array}{l}\mathbf{n} \\
(2) \\
\end{array}$} & \multirow{2}{*}{$\begin{array}{l}\% \\
(3) \\
\end{array}$} & \multirow{2}{*}{$\begin{array}{c}\text { Rata-rata } \\
(4)\end{array}$} \\
\hline & (1) & & & \\
\hline & Laki-laki & 266 & $93 \%$ & \\
\hline Jenis Kelamın & Perempuan & 21 & $7 \%$ & \\
\hline \multirow{2}{*}{ Tempat tinggal } & Desa & 161 & $56 \%$ & \\
\hline & Kota & 126 & $44 \%$ & \\
\hline Tingkat & $\begin{array}{l}\text { Tidak tamat/ tamat } \\
\text { pendidikan dasar }\end{array}$ & 115 & $40 \%$ & \\
\hline \multirow[t]{2}{*}{ Pendidikan } & Tamat pendidikan menengah & 123 & $43 \%$ & \\
\hline & Tamat pendidikan tinggi & 49 & $17 \%$ & \\
\hline Usia (tahun) & & & & 36 \\
\hline Lama Berprofes & hun) & & & 17 \\
\hline Pendapatan (pe & inggu) & & & $\operatorname{Rp} 450.000,00$ \\
\hline
\end{tabular}

Rata-rata perajin ukir kayu Jepara berusia 36 tahun dan sudah menekuni profesi sebagai perajin ukir selama kurang lebih 17 tahun. Sistem pemberian gaji atau upah dari pemilik usaha kepada perajin dilakukan seminggu sekali dengan metode pembayaran harian atau borong, rata-rata pendapatan per minggu perajin ukir kayu Jepara adalah 450 ribu rupiah.

\section{Latar Belakang Profesi Perajin Ukir Kayu}

Menurut sejarah, seni ukir pertama kali masuk ke Jepara pada 1559. Keterampilan mengukir masyarakat Jepara diwarisi secara turun-temurun dan merupakan suatu tradisi yang harus dilestarikan (Kartajaya, 2005: 224). Sistem pewarisan yang dilakukan secara turun temurun seperti ini mempunyai arti yang sangat penting bagi kelangsungan dan perkembangan industri seni mebel ukir. Seiring berjalannya waktu, Jepara dikenal sebagai pusat industri mebel ukir di Indonesia. Produk industri mebel ukir Jepara telah berhasil memasuki pasar internasional dan global. Kehadiran produk seni tersebut mendapat tanggapan positif dari konsumen mancanagara, terutama di Asia, Eropa Barat, dan Amerika sehingga disematkan julukan untuk Kota Jepara sebagai Kota Ukir atau The Carving Centre of Indonesia (Gustami, 2000: 4).

Proses seni ukir masuk ke Jepara seperti inilah yang membuat mayoritas warga Jepara lebih memilih berprofesi sebagai perajin ukir dan mencoba menekuninya. Gambaran profesi perajin ukir kayu menurut perajin ukir kayu Jepara disajikan dalam Tabel 3.

Alasan yang mendasari perajin ukir dalam memilih profesi adalah lingkungan sekitar (teman atau tetangga), tidak memiliki keahlian lain, dan tradisi keluarga. Faktor tersebut ada karena saran dari orang tua atau keluarga yang menginginkan untuk ikut serta dalam melestarikan tradisi turun-temurun 
Tabel 3. Alasan Menjadi Perajin Ukir Kayu Jepara

dan Keinginan Beralih Profesi Lain

\begin{tabular}{|c|c|c|}
\hline \multicolumn{2}{|c|}{ Informasi Profesi Perajin Ukir Kayu } & \multirow{2}{*}{$\begin{array}{c}\% \\
(2)\end{array}$} \\
\hline$(1)$ & & \\
\hline & Tradisi keluarga & $11,1 \%$ \\
\hline $\begin{array}{l}\text { Alasan memilih profesi } \\
\text { perajin ukir }\end{array}$ & $\begin{array}{l}\text { Lingkungan sekitar (teman/ tetangga) } \\
\text { Tidak punya keahlian lain } \\
\text { Lainnya }\end{array}$ & $\begin{array}{l}44,9 \% \\
29,8 \% \\
14,2 \%\end{array}$ \\
\hline $\begin{array}{l}\text { Menyarankan profesi } \\
\text { perajin ukir }\end{array}$ & $\begin{array}{l}\text { Orang tua/ keluarga } \\
\text { Teman/ tetangga } \\
\text { Lainnya }\end{array}$ & $\begin{array}{c}100,0 \% \\
0,0 \% \\
0,0 \%\end{array}$ \\
\hline $\begin{array}{l}\text { Keinginan beralih profesi } \\
\text { dari perajin ukir }\end{array}$ & $\begin{array}{l}\text { Ya } \\
\text { Tidak }\end{array}$ & $\begin{array}{l}57,1 \% \\
42,9 \%\end{array}$ \\
\hline $\begin{array}{l}\text { Alasan beralih dari profesi } \\
\text { perajin ukir }\end{array}$ & $\begin{array}{l}\text { Pendapatan lebih besar } \\
\text { Pekerjaan lebih mudah } \\
\text { Bosan } \\
\text { Lainnya }\end{array}$ & $\begin{array}{c}59,1 \% \\
11,0 \% \\
6,1 \% \\
23,8 \%\end{array}$ \\
\hline $\begin{array}{l}\text { Profesi pilihan selain } \\
\text { perajin ukir }\end{array}$ & $\begin{array}{l}\text { Bekerja di lembaga pemerintahan/ kantoran } \\
\text { Bidang pertanian } \\
\text { Bidang industri lain } \\
\text { Lainnya }\end{array}$ & $\begin{array}{c}13,4 \% \\
9,1 \% \\
36,0 \% \\
41,5 \%\end{array}$ \\
\hline $\begin{array}{l}\text { Alasan tidak ingin beralih } \\
\text { dari profesi perajin ukir }\end{array}$ & $\begin{array}{l}\text { Pendapatan sudah cukup } \\
\text { Sudah merasa nyaman } \\
\text { Lainnya }\end{array}$ & $\begin{array}{l}4,9 \% \\
74,0 \% \\
21,1 \%\end{array}$ \\
\hline
\end{tabular}

Sumber: data primer (diolah)

masyarakat Jepara. Namun, kenyataannya banyak perajin ukir kayu yang ingin beralih profesi karena merasa bahwa pendapatan yang diperoleh dari profesi lain lebih besar. Dengan demikian, perajin lebih memilih untuk beralih profesi lain. Profesi pilihan tersebut terdiri atas bidang pemerintahan, pertanian, dan industri. Berdasarkan Tabel 3 terkait profesi pilihan, jawaban "lainnya" merupakan yang terbanyak diantara pilihan lainnya. Meski terdapat keinginan untuk beralih profesi, perajin ukir kayu Jepara masih memilih profesi di bidang seni ukir kayu. Profesi tujuan yang dimaksud adalah menjadi pengusaha ukir, bukan lagi sebagai perajin ukir kayu. Pengusaha ukir merupakan atasan (bos) dari perajin ukir kayu. Perannya sebagai manajer dalam memasarkan hasil ukiran kayu membuat perajin ukir ingin mencoba pengalaman tersebut.

Minat dan Kebahagiaan sebagai Perajin Ukir Kayu Berdasarkan Karakteristik Sosial Ekonomi

Minat diukur dengan menggunakan skor kumulatif dari 19 pernyataan yang terdapat dalam kuesioner. Masing-masing pernyataan memiliki pilihan jawaban persetujuan dengan 
nilai tidak setuju (1), kurang setuju (2), setuju (3) dan sangat setuju (4). Pernyataan tersebut berdasarkan indikator pengukuran minat ditinjau dari faktor internal (pribadi kerja, pendidikan, status ekonomi, dan emosional) dan faktor eksternal (kondisi pekerjaan, fasilitas, dan tradisi).

Dengan demikian, diperoleh dua kategori minat, yaitu berminat dan cukup berminat yang proses pengategoriannya diuraikan seperti berikut:

\section{Minat}

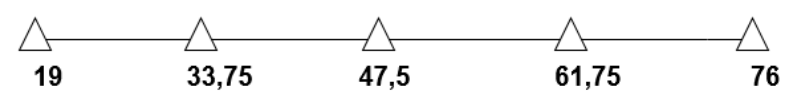

Skor 19-33 : Kurang Berminat

Skor 34-61 : Cukup Berminat

Skor 62-76 : Berminat

Berdasarkan skor tersebut, minat perajin ukir kayu Jepara berada dalam kategori cukup berminat atau sebesar $88 \%$. Adapun karakteristik perajin yang cukup berminat dijelaskan dalam Tabel 4 berikut Gambar 1, Gambar 2, dan Gambar 3.

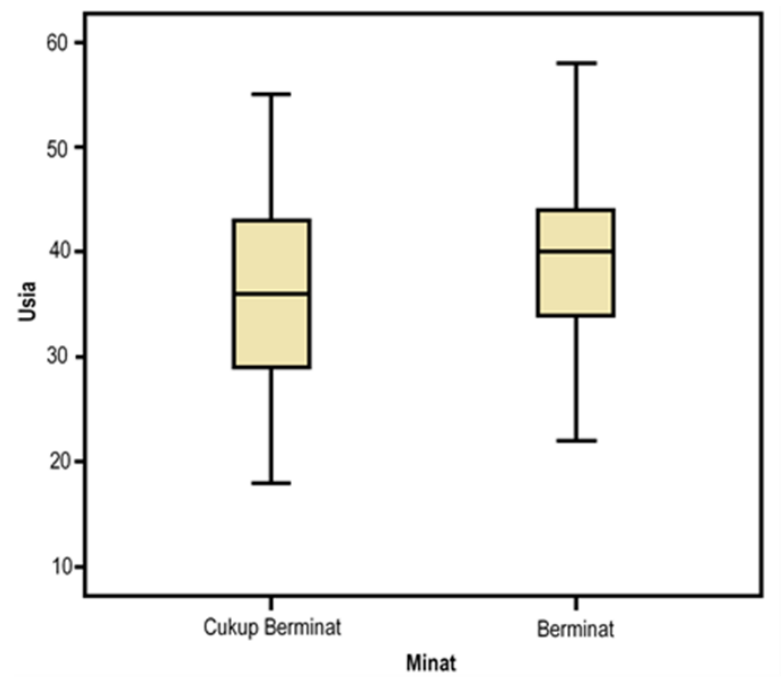

Gambar 1. Kotak Plot Kategori Minat dengan Usia

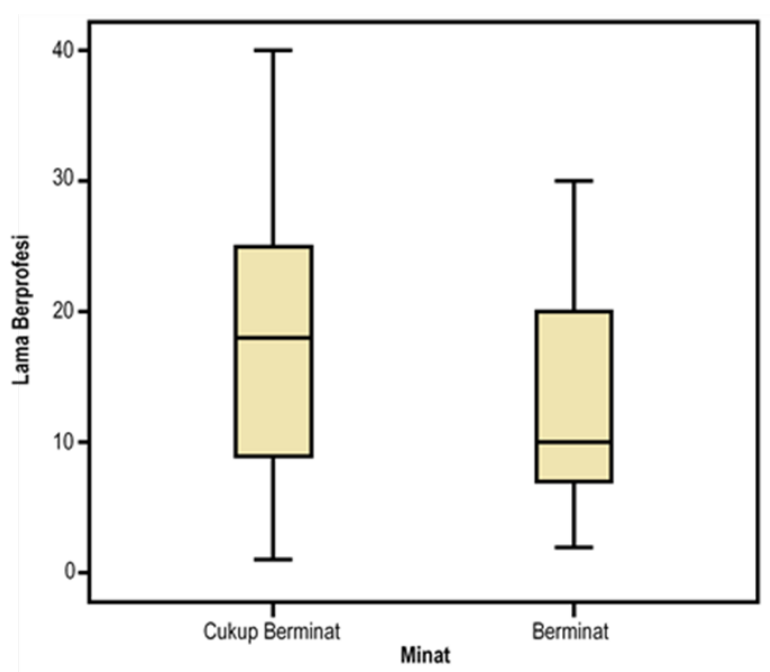

Gambar 2. Kotak Plot Kategori Minat dengan Lama Berprofesi

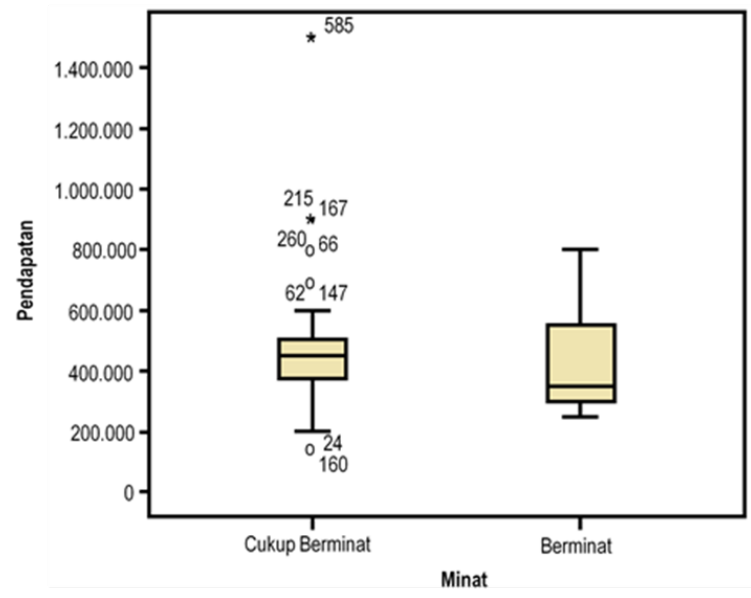

Gambar 3. Kotak Plot Kategori Minat dengan Pendapatan

Berdasarkan Tabel 4 dan 5 serta Gambar 1, 2 dan 3, perajin ukir yang cukup berminat, sebagian besar berpendidikan dasar, rata-rata berusia 36 tahun (dewasa muda), memiliki rata-rata pendapatan per minggu sebesar 450 ribu rupiah dan telah menekuni profesi sealam kurang lebih 18 tahun.

Kebahagiaan perajin ukir kayu Jepara diukur berdasarkan skor kumulatif dari tujuh indikator pernyataan mengenai kebahagiaan non finansial dan finansial. Pernyataan berupa skala penilaian 0-10 tentang skor kebahagiaan untuk masing-masing 
Tabel 4. Perbedaan Minat sebagai Perajin Ukir Kayu Berdasarkan Tingkat Pendidikan

\begin{tabular}{llccc}
\hline & & \multicolumn{3}{c}{ Tingkat Pendidikan } \\
\cline { 3 - 5 } & & $\begin{array}{c}\text { Tidak tamat/ tamat } \\
\text { pendidikan dasar }\end{array}$ & $\begin{array}{c}\text { Tamat pendidikan } \\
\text { menengah }\end{array}$ & $\begin{array}{c}\text { Tamat pendidikan } \\
\text { tinggi }\end{array}$ \\
\hline \multirow{2}{*}{ Minat } & Berminat & $(2)$ & $(3)$ & $(4)$ \\
\cline { 3 - 5 } & Cukup Berminat & $5,2 \%$ & $14,6 \%$ & $22,4 \%$ \\
\hline
\end{tabular}

Sumber: data primer (diolah)

Tabel 5. Perbedaan Minat sebagai Perajin Ukir Kayu Berdasarkan Tempat Tinggalnya

\begin{tabular}{llcc}
\hline & & \multicolumn{2}{c}{ Tempat Tinggal } \\
\cline { 3 - 4 } & & Desa & Kota \\
\hline \multirow{2}{*}{ Minat } & $(1)$ & $(2)$ & $(3)$ \\
& Berminat & $10,6 \%$ & $14,3 \%$ \\
& Cukup Berminat & $89,4 \%$ & $85,7 \%$ \\
\hline
\end{tabular}

Sumber: data primer (diolah)

Tabel 6. Kebahagiaan Perajin Ukir Kayu

Indikator Kebahagiaan Kerja

Rata-Rata Skor

Kebahagiaan

(1)

Kenyamanan dalam berprofesi

Bangga dalam menghasilkan karya

Bangga jika karya mendapat apresiasi

Bahagia jika karya terjual dengan harga tinggi

Bahagia jika mendapat pesanan

Bahagia dalam melestarikan tradisi

Rata-rata penghasilan/ minggu

Sumber: data primer (diolah)
(2)

61

52

60

49

60

50

58

49

59

49

58

57

56

61

Rp 1.000.000,00

57 
indikatornya (kebahagiaan non finansial, yaitu kenyamanan dalam berprofesi, kebanggan dalam menghasilkan karya, apresiasi dan melestarikan tradisi) dan (kebahagiaan finansial, yaitu besarnya pendapatan, harga jual ukiran dan saat mendapat pesanan). Berikut merupakan gambaran skor kebahagiaan perajin ukir kayu Jepara berdasarkan indikator kebahagiaan yang digunakan dalam penelitian ini.

Kemudian diperoleh dua kategori kebahagiaan, yaitu bahagia dan cukup bahagia yang pengategoriannya adalah sebagai berikut:

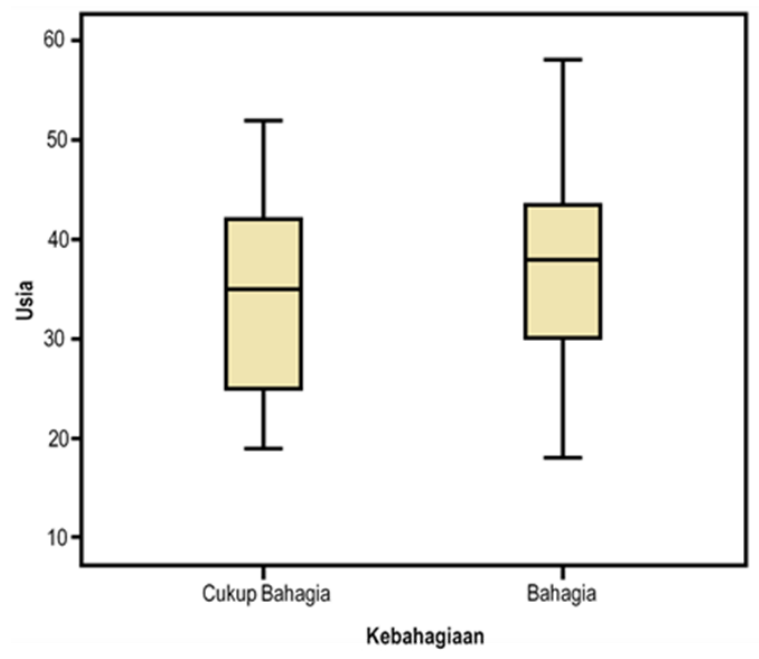

Gambar 4. Kotak Plot Kategori Tingkat Kebahagiaan dengan Usia

\section{Kebahagiaan}

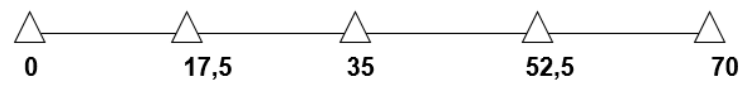

Skor 0-17 : Kurang Bahagia

Skor 18-52 : Cukup Bahagia

Skor 53-70 : Bahagia

Berdasarkan hasil penelitian, tingkat kebahagiaan perajin ukir kayu Jepara berada dalam kategori bahagia, yaitu 78\%. Adapun karakteristik perajin yang bahagia dijelaskan dalam tabel dan grafik sebagai berikut.

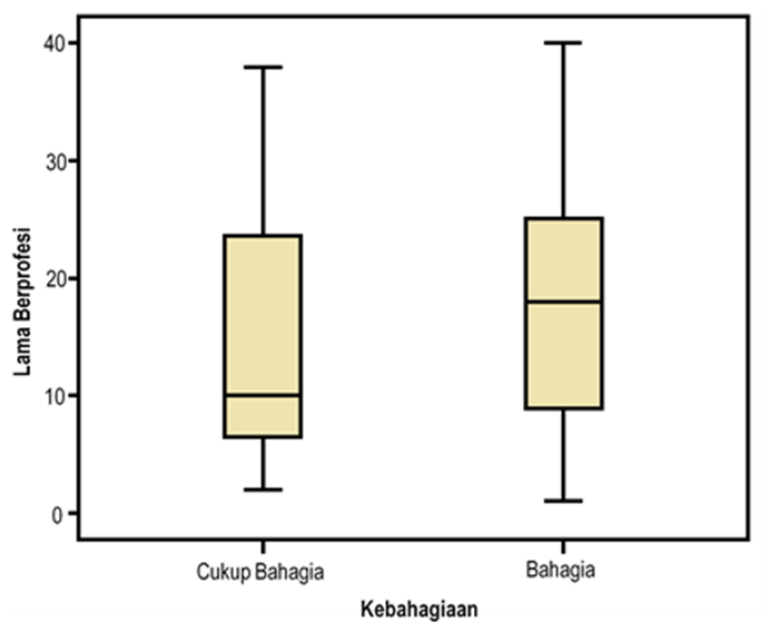

Gambar 5. Kotak Plot Kategori Tingkat Kebahagiaan dengan Lama Berprofesi

Tabel 7. Perbedaan Kebahagiaan Perajin Ukir Kayu Berdasarkan Tingkat Pendidikan

Tingkat Pendidikan

Tidak lulus/ lulus Lulus pendidikan Lulus pendidikan pendidikan dasar menengah tinggi

(1)

Bahagia

Kebahagiaan
(2)

$78,3 \%$

$21,7 \%$
(3)

$78,0 \%$

(4)

$77,6 \%$

Cukup Bahagia

$22,0 \%$
$22,4 \%$

Sumber: data primer (diolah) 
Tabel 8. Perbedaan Kebahagiaan sebagai Perajin Berdasarkan Tempat Tinggalnya

\begin{tabular}{llcc}
\hline & & \multicolumn{2}{c}{ Tempat Tinggal } \\
\cline { 3 - 4 } & $(1)$ & Desa & Kota \\
\hline \multirow{2}{*}{ Kebahagiaan } & Bahagia & $(2)$ & $(3)$ \\
\hline & Cukup Bahagia & $80,1 \%$ & $75,4 \%$ \\
\hline
\end{tabular}

Sumber: data primer (diolah)

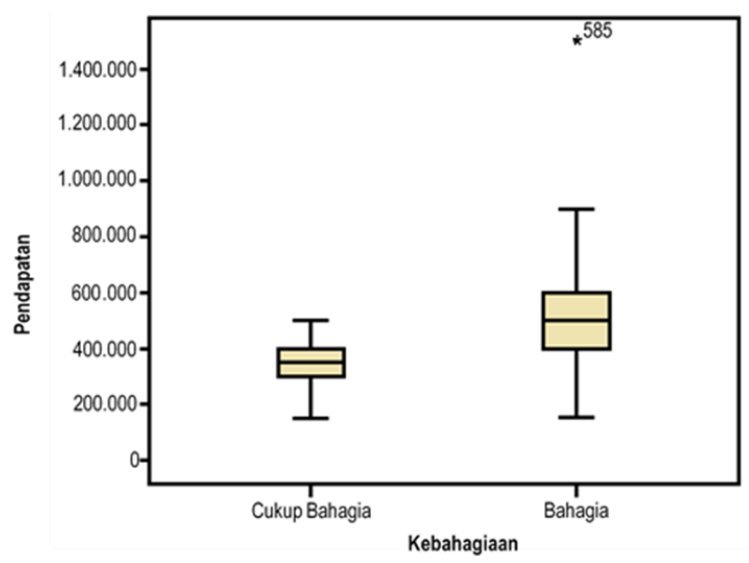

Gambar 6. Perbedaan Tingkat Kebahagiaan Berdasarkan Tempat Tinggalnya

Berdasarkan Tabel 7 dan 8 serta Gambar 4, 5 dan 6, perajin ukir pada setiap jenjang pendidikannya merasa bahagia, rata-rata berusia 35 tahun (dewasa muda), memiliki rata-rata pendapatan per minggu sebesar 350 ribu dan telah menekuni profesi selama kurang lebih 16 tahun.
Pengaruh Karakteristik Sosial Ekonomi dan Minat terhadap Tingkat Kebahagiaan Perajin Ukir Kayu

Salah satu tujuan penelitian ini adalah untuk menganalisis hubungan antara minat dan kebahagiaan sebagai perajin ukir kayu. Untuk melihat hubungan tersebut, uji kebebasan (test of independency) dilakukan. Hasil yang diperoleh menunjukkan adanya hubungan antara minat dan kebahagiaan. Hal ini dibuktikan dengan nilai signifikansi $(\alpha=0,041)$ yang lebih kecil dari taraf uji lima persen $(0,05)$, seperti hasil pengolahan sebagai berikut.

Selain minat, karakteristik sosial ekonomi perajin ukir kayu juga dinilai dapat memengaruhi tingkat kebahagiaan perajin. Berdasarkan pembahasan sebelumnya, minat perajin dibagi menjadi dua dan telah

\section{Chi-Square Tests}

\begin{tabular}{lcclll}
\hline & Value & df & $\begin{array}{l}\text { Asymp. Sig. } \\
\text { (2-sided) }\end{array}$ & $\begin{array}{l}\text { Exact Sig. } \\
\text { (2-sided) }\end{array}$ & $\begin{array}{l}\text { Exact Sig. } \\
\text { (1-sided) }\end{array}$ \\
\hline $\begin{array}{lllll}\text { Pearson Chi-Square } \\
\text { Continuity }\end{array}$ & $4,165^{\mathrm{a}}$ & 1 &, 041 & & \\
$\begin{array}{l}\text { Correction } \\
\text { b }\end{array}$ & 3,323 & 1 &, 068 & & \\
$\begin{array}{l}\text { Likelihood Ratio } \\
\text { Fisher's Exact Test }\end{array}$ & 4,982 & 1 &, 026 &, 049 &, 027 \\
N of Valid Cases & 287 & & & & \\
\hline
\end{tabular}


diuraikan berdasarkan karaktersitik sosial ekonomi. Kemudian dilakukan pengujian dengan analisis regresi logistik biner untuk mengetahui seberapa besar pengaruh karakteristik sosial ekonomi dan minat terhadap kebahagiaan perajin.

Pengujian Karakteristik Sosial Ekonomi dan Minat terhadap Kebahagiaan Perajin Ukir Kayu Jepara
Berdasarkan analisis regresi logistik biner, variabel yang berpengaruh signifikan terhadap tingkat kebahagiaan perajin ukir kayu Jepara adalah pendidikan, pendapatan, dan minat. Hal ini dibuktikan dengan nilai pada uji wald pada langkah 4 yang mengikuti distribusi chisquare, dimana $W>X_{a ; 1}^{2}$ atau $W>\left(X_{0,05 ; 1}^{2}=\right.$ $3,84)$, atau dengan kata lain, nilai signifikansi (a) pada langkah $4<0,05$.

\section{Variables in the Equation}

\begin{tabular}{|c|c|c|c|c|c|c|c|}
\hline & & $\mathrm{B}$ & S.E. & Wald & $\mathrm{df}$ & Sig. & $\operatorname{Exp}(B)$ \\
\hline \multirow{7}{*}{ Step $1^{a}$} & Wilayah(1) &, 144 & ,350 & ,170 & 1 &, 680 & 1,155 \\
\hline & Pendidikan(1) &,- 846 & ,451 & 3,522 & 1 &, 061 & ,429 \\
\hline & Pendapatan(1) & 3,213 & ,448 & 51,318 & 1 &, 000 & 24,847 \\
\hline & Usia & ,004 & ,035 & ,011 & 1 &, 915 & 1,004 \\
\hline & Lama_Berprofesi & ,009 & ,034 & ,076 & 1 & ,782 & 1,009 \\
\hline & Minat (1) & 2,085 & ,719 & 8,397 & 1 &, 004 & 8,041 \\
\hline & Constant &,- 028 & 1,053 & ,001 & 1 & ,979 &, 972 \\
\hline \multirow{6}{*}{ Step $2^{a}$} & Wilayah(1) & ,139 & ,347 & ,161 & 1 & ,688 & 1,149 \\
\hline & Pendidikan(1) &,- 854 & ,444 & 3,702 & 1 &, 054 & ,426 \\
\hline & Pendapatan(1) & 3,209 & ,447 & 51,593 & 1 &, 000 & 24,743 \\
\hline & Lama_Berprofesi &, 012 & ,020 &, 370 & 1 &, 543 & 1,012 \\
\hline & Minat (1) & 2,110 & ,681 & 9,607 & 1 &, 002 & 8,245 \\
\hline & Constant & ,066 & ,570 & ,013 & 1 & ,908 & 1,068 \\
\hline \multirow{5}{*}{ Step $3^{a}$} & Pendidikan (1) &,- 863 & ,443 & 3,788 & 1 &, 052 & ,422 \\
\hline & Pendapatan(1) & 3,186 & ,443 & 51,772 & 1 &, 000 & 24,203 \\
\hline & Lama_Berprofesi & ,012 & ,020 & ,359 & 1 &, 549 & 1,012 \\
\hline & Minat (1) & 2,105 & ,679 & 9,614 & 1 &, 002 & 8,204 \\
\hline & Constant & ,148 & ,533 & ,077 & 1 & ,781 & 1,159 \\
\hline \multirow{4}{*}{ Step $4^{a}$} & Pendidikan(1) & $-1,012$ &, 369 & 7,526 & 1 &, 006 & ,364 \\
\hline & Pendapatan(1) & 3,214 & ,441 & 53,146 & 1 &, 000 & 24,880 \\
\hline & Minat (1) & 2,068 & ,673 & 9,432 & 1 &, 002 & 7,912 \\
\hline & Constant & ,429 & ,255 & 2,821 & 1 & ,093 & 1,536 \\
\hline
\end{tabular}


Tabel 9. Penduga Parameter, Uji Wald, dan Odds Ratio Karakteristik Sosial Ekonomi dan Minat Perajin

\begin{tabular}{llllllll}
\hline & & B & S.E. & Wald & df & Sig. & Exp(B) \\
\hline & & & & & & & \\
\hline & $(1)$ & $(2)$ & $(3)$ & $(4)$ & $(5)$ & $(6)$ & $(7)$ \\
\hline \multirow{2}{*}{ Step 1 } & Pendidikan(1) & $-1,012$ & 0,369 & 7,526 & 1 & 0,006 & 0,364 \\
& Pendapatan(1)* & 3,214 & 0,441 & 53,146 & 1 & 0,000 & 24,880 \\
& Minat(1)* & 2,068 & 0,673 & 9,432 & 1 & 0,002 & 7,912 \\
& Constant &, 429 & 0,255 & 2,821 & 1 & 0,093 & 1,536 \\
\hline
\end{tabular}

Dengan demikian, hanya ketiga variabel tersebut yang dimasukkan dalam pengujian model kebahagiaan perajin ukir kayu Jepara.

Persamaan regresi logistik biner yang dihasilkan berdasarkan Tabel 9:

$$
\begin{aligned}
\hat{g}(D)= & 0,429+(-1,012) D_{1}^{*}+3,214 D_{2}^{*} \\
& +2,068 D_{3}^{*}
\end{aligned}
$$

Keterangan:

$\mathrm{D}:$ dummy tingkat pendidikan;

$\mathrm{D}_{2}$ : dummy pendapatan;

$\mathrm{D}_{3}$ : dummy minat.

Kecenderungan tertinggi perajin ukir kayu Jepara untuk bahagia bergantung pada besarnya pendapatan. Pendapatan yang diterima digunakan untuk mencukupi kebutuhan sehari-hari dan kebutuhan lainnya, seperti usaha di bidang lain, menyekolahkan anak, membayar cicilan motor, atau barang elektronik dan perawatan peralatan ukir kayu. Selain itu, mereka juga dibebani oleh kewajiban membayar hutang sebagai akibat dari ketidakmampuan untuk mencukupi kebutuhan sehari-hari.
Selain pendapatan, faktor minat juga cenderung membuat perajin ukir kayu Jepara merasa bahagia. Berdasarkan analisis deskriptif, perajin ukir kayu tidak lebih berminat dalam menekuni profesinya, melainkan termasuk dalam kategori cukup berminat. Hal tersebut disebabkan oleh beberapa faktor, seperti perajin yang memilih profesi sebagai perajin ukir didasarkan atas lingkungan sekitar (teman atau tetangga), tidak memiliki keahlian selain mengukir dan faktor dorongan dari orang tua atau keluarga yang merupakan tradisi turun-temurun.

Faktor lainnya adalah perajin memiliki minat dalam kategori cukup yang ditunjukkan dengan adanya keinginan untuk beralih profesi, dengan harapan mereka dapat memperoleh pendapatan yang lebih besar dari pendapatan perajin ukir. Meski demikian, tidak semua perajin ingin beralih profesi, terdapat beberapa perajin yang sudah merasa nyaman dan senang dalam menekuni profesinya. 


\section{Kesimpulan}

Berdasarkan hasil dan pembahasan tersebut, kesimpulan yang dapat diambil dari penelitian ini adalah sebagai berikut.

i. Sebagian besar perajin ukir kayu Jepara adalah perajin yang tempat tinggalnya berasal dari desa, berpendidikan dasar dan menengah, tergolong usia dewasa muda, telah menekuni profesi kurang lebih 17 tahun, dan berpendapatan rendah.

ii. Minat perajin ukir kayu Jepara berada dalam kategori "cukup berminat" dan memiliki tingkat kebahagiaan dalam kategori "bahagia".

iii. Terdapat hubungan antara minat dan tingkat kebahagiaan. Selain minat, faktor lain yang memengaruhi tingkat kebahagiaan perajin adalah tingkat pendidikan dan pendapatan.

iv. Kecenderungan tertinggi perajin ukir kayu Jepara merasa bahagia adalah besarnya pendapatan. Namun, minat juga cenderung membuat perajin ukir kayu Jepara merasa bahagia.

Selanjutnya, beberapa langkah yang dapat diambil terkait hasil dan pembahasan dalam penelitian ini adalah sebagai berikut.

i. Bagi Perajin Ukir Kayu

Para perajin ukir kayu dharapkan untuk lebih merasa nyaman dalam menjalani profesi, memiliki kebanggan atas karya yang dihasilkan, dan merasa bahagia untuk menjaga tradisi atau budaya.

ii. Bagi Pemilik Usaha

a. Memberikan gaji atau upah yang sesuai dengan Upah Minimum Regional (UMR);

b. Memastikan kelengkapan dan fasilitas kerja untuk meningkatkan produktivitas; c. Menciptakan suasana kerja yang nyaman dan memotivasi perajin ukir kayu untuk menjalani profesi.

iii. Bagi Pemerintah

a. Membantu memasarkan produk seni ukir Jepara, misalnya melakukan kerja sama dengan instansi, lembaga, atau badan milik pemerintah atau swasta;

b. Aktif melestarikan tradisi dan budaya mengukir masyarakat Jepara, yaitu dengan memperhatikan kesejahteraan perajin ukir kayu agar perajin tidak beralih profesi dan seni ukir Jepara tidak punah.

\section{Daftar Pustaka}

A. Crow, dan Crow, L. (1998). Educational Pshychology. Surabaya: Bina Ilmu.

Agresti, A. (2000). Categorical Data Analysis (2nd ed). New York: John Wiley \& Sons.

Alfarisi. (2010). Hubungan Antara Kepuasan

Kerja dengan Produktivitas Pada Guru. Skripsi. Sarjana Fakultas Psikologi, Riau Islamic University.

Asra, Abuzar; Irawan, Puguh B; Purwoto, Agus.(2015). Metode Penelitian Survei. Bogor: IN MEDIA.

Badan Pusat Statistik. (2015). "Banyaknya

Unit Usaha dan Tenaga Kerja dirinci menurut Jenis Industri Kecil Menengah di Kabupaten Jepara (IKM), 2015". https:// jeparakab.bps.go.id/linkTabelStatis/view. id.489, diakses 09 Desember 2017.

Badan Pusat Statistik. (2017). Indeks Kebahagiaan 2017. Jakarta: BPS.

Berliana, Sarni M; Irawan, Puguh B; Usman, Hardius dan Wicaksono, Febri. (2016). Official Statistics. Bogor: In Media.

Bustomi, Suwaji. (1982). Landasan

Berapresiasi Seni Rupa. Semarang: 


\section{Proyek Peningkatan Perguruan Tinggi IKIP.}

CIFOR. (2012). Pelangi di Tanah Kartini. Bogor: CIFOR.

Dewan Ketahanan Nasional RI. (2016). "Jumlah Pulau di Indonesia". https:// dkn.go.id/ruang-opini/9/jumlah-pulau-diindonesia.html, diakses 04 Februari 2018.

Diener, E. (2003). The Happy Worker : Hypothesis About The Role Of Possitive Affect in Worker Productivity. San Francisco: Jossey-Bass.

Dinas Perindustrian dan Perdagangan Kabupaten Jepara. (2010). Data Nilai Produksi Potensi Industri Kabupaten Jepara. Jepara: DISPERINDAG.

Dinas Perindustrian dan Perdagangan Kabupaten Jepara. (2015). Ekspor Mebel Jepara. Jepara: DISPERINDAG.

Dinas Perindustrian dan Perdagangan Kabupaten Jepara. (2016). Potensi Industri IKM Kabupaten Jepara. Jepara: DISPERINDAG.

Elizabeth, S.D. (2008). Analisis Pertumbuhan Produksi Ukir Kayu Jepara. Skripsi. Sarjana Fakultas Ekonomi, Universitas Indonesia.

Eskak, Edi. (2013). "Krisis Bahan Baku Seni Kerajinan Kayu di Jepara dan Solusi Pemecahannya". KEMENPERIN 30 (2), 13-20.

Gressy Septarini, Berlian; Hakim Lukman. (2014). "Hubungan antara otonomi kerja dengan Kebahagiaan kerja pada industri kreatif (relation of work autonomy with happiness at Work in creative industry)". Psikologi Industri dan Organisasi 03 (1), 46-58.

Gustami S.P. (2000). Seni Kerajinan Meubel Ukir Jepara: Kajian Estetika Melalui Pendekatan Multidisiplin.Yogyakarta: Kanisius.

Kementerian Perindustrian RI. (2013). "Krisis Bahan Baku Seni Kerajinan Kayu di Jepara dan Solusi Pemecahannya". https://ejournal.kemenperin.go.id, diakses 05 November 2017.

Kartajaya, Hermawan. (2005). "Attracting tourists, traders, investors: strategi memasarkan daerah di era otonomi". https://books.google.co.id/books?id= 9B9MO263kQYC\&dq=sejarah+seni+ ukir+kayu+jepara \&hl=id\&source= gbs_navlinks_s, diakses 03 Februari 2018. Lopez dan Snyder. (2007). Positive Psychology: The Scientific and Practical Ex plorations of Human Strengths. Lawrence : University of Kansas.

Priyanto, H. 2013. Mozaik Seni Ukir Jepara. Jepara: Lembaga Pelestarian Seni Ukir, Batik, dan Tenun Jepara.

Purwaningsih, Erna. (2016). "Pengaruh Minat Menanam Kedelai (Glycine max (L.) Merr.) Terhadap Indeks Kebahagiaan (Happiness Index) Petani Grobogan Jawa Tengah". Skripsi. Sarjana Departemen Teknologi Industri Pertanian, Universitas Gadjah Mada.

Sandra, Dewi Elisabeth. (2008). "Analisis Pertumbuhan Produksi Ukir Kayu Jepara". Skripsi. Sarjana Jurusan Ekonomi Pembangunan, Fakultas Ekonomi. Universitas Indonesia.

Slameto. (2010). "Belajar dan FaktorFaktor yang Mempengaruhinya". https:// davamelodica.com/teori-minat-padaskripsi-pendidikan/, diakses 03 Februari 2018.

Tazqiyah, Aniqatul. (2010). "Minat Anak Keluarga Perajin Ukiran Melanjutkan Pendidikan ke Perguruan Tinggi (Studi Kasus di Desa Mulyoharjo Kecamatan Jepara Kabupaten Jepara)". Skripsi. Sarjana Jurusan Pendidikian Sosiologi dan Antropologi, Universitas Negeri Semarang. 